\title{
A Tale of Two Brazzas: Intertwining (Post-)Colonial Namescapes
}

\author{
LIORA BIGON
}

General Studies Department, Holon Institute of Technology (HIT), Holon, Israel

\author{
Michel Ben Arrous \\ General History Department, Bar Ilan University, Ramat Gan, Israel
}

This article brings together and analyzes two toponyms: Brazzaville Street in Holon, Israel, and Quay of Brazza in Bordeaux, France. In the light of historical and contemporary developments at different points of time, geographies and socio-political contexts, the crisscrossing between both Brazza-related toponyms is useful in promoting a critical and more nuanced interpretation of space and nomenclature. In exploring the varied flows of power, ambiguities and tensions behind the two place names, and in bringing the Congo to the fore, the article also relates to geographies beyond Europe. This aspect of spatial intertwining contributes to the de-Eurocentrization of recent place names studies, which tend to be focused on Europe/the West and on nationalistic aspects. In addition, a variety of primary and secondary materials is employed, including visual and archival sources, and fieldwork.

KEYWoRds Brazza, Brazzaville, Holon/Israel, Bordeaux/France, Congo, interconnected geographies, (post-)colonial history, street signage, toponymic studies.

After years of extensive research on place names in Africa (Bigon 20I6; Bigon and Katz 20I7) and the meanings of place itself in postcolonial contexts (Ben Arrous 20I2, 2015), we realized that the closest affiliation to a common street name in both our cities Holon, a suburban town bordering Tel Aviv, and Bordeaux in south-western France was related to the Congo. There exists a short Brazzaville Street in Holon and there is a long Quay of Brazza in Bordeaux. The latter commemorates the Italo-French explorer, Pierre Savorgnan de Brazza (I852-I905), whose name was given to the capital of Congo and thus, by extension, to Brazzaville Street in Holon.

This article takes an interactive approach to understanding the present-day complexities of the two Brazza-related toponyms in the light of the different historical contexts in 
the two loci of study. It illustrates the importance of "entangled histories." "Entangled histories" (Randeria 2009), sometimes called in transnational studies "connected histories" (Subrahmanyam I997) or "histoire croisée” (Werner and Zimmermann 2006) - a useful approach in our case as it recognizes historical and contemporary entanglements between variegated geographical spheres in a flexible way, at different points of time in different societies. This relational (rather than comparative) and process-oriented approach also questions neat perceptual or practical demarcations by recognizing the varied flows of power, ambiguities and tensions, irrespective of geographical origins. Moreover, this approach facilitates examining interactions involving a variety of directions and multiple effects, combinations and transformations - as products of hybridization that bring us beyond the original elements. As will be shown later, the entanglement between the two Brazza-related toponyms in Holon and Bordeaux breaks the site-related essentialism of each toponym by "paying particular attention to the consequences of intercrossing" (Werner and Zimmermann 2006, 42) - consequences in terms of original interpretations produced by this toponymic intercrossing.

Research trends in place-name studies are characterized, since the post-I990s period, as a "critical turn" in place-name scholarship, excitingly producing in their "explicit and self-reflexive engagement with critical theories of space and place" a "new body of research, which situates the study of toponymy within the context of broader debates in critical human geography" (Rose-Redwood, Alderman, and Azaryahu 20I0, 455). This period is clearly different from the more antiquarian and taxonomical approaches featured in most pre-I990s research. The latter was governed by linguists and topographers rather than by historians, human geographers or political scientists. Thus, its concerns remained somewhat parochial, limited to toponymic etymology and typology, with hardly any interdisciplinary influence.

It has been clearly acknowledged in recent toponymic studies that, beyond the primary purpose of place names as an administrative act designated to facilitate spatial orientation, the symbolic and socio-political aspects of their production must also be taken into account. Yet these studies are over-concerned with modern political regimes, nationalism, and ideology — and refer almost exclusively to inter-Western/European contexts (e.g. Jones and Merriman 2009; Light, Nicolae, and Suditu 2002; Milo I997; Nash 1999; Raento and Watson 2000; Rose-Redwood 2008). Within these contexts, amongst the issues that have received the most attention are "nationalism, revolutions and wars of independence" (Foote and Azaryahu 2007, I25-I26). This article not only interconnects between the two different site-related contexts, histories, time spans and socio-politics of Holon and Bordeaux; it also mediates between geographies beyond Europe, by interconnecting France, Israel and the Congo.

Our Holon starting point bore the promise of a refreshing and somewhat ironic viewpoint. Refreshing, because a street named after an African city constitutes a rare bird in the Israeli namescape. Street naming or, more broadly, toponymy, tends, in this country, to operate as a powerful mechanism for the symbolic construction of the public space, instrumental in conveying nationalistic agendas and demarcating borders between ethno-linguistic groups. In Israel, as in other countries where several national communities speaking different languages co-exist, linguistic landscapes mirror ideological, political and cultural conflicts that shape the identity of place (Ben-Rafael et al. 2006; Fishman et al. 1985; Shohamy and Donitsa-Schmidt I988; Suleiman 2004). With this in mind, it is safe to argue that Israeli geographers and historians developed an academic tradition 
of questioning and debating place naming that has few if any equivalents in the world. They have produced a distinctive and considerable corpus of critical research literature that continues to grow. Much of it revolves around historical geography and ideological aspects of (post-)Zionism, within Jewish society (e.g. Bar-Gal I989, I999; Katz I995, I999); and, against the background of the Israeli-Palestinian conflict, around competing spatial challenges with relation to national identity, ethno-linguistics, and collective memories (Azaryahu and Kellerman I999; Benvenisti 2000; Bigon and Dahamshy 2014; Shoval 20I3). Nothing could be further from our Brazzaville Street!

From time to time, Israeli place names are also debated in the mainstream press, with (mostly) passionate articles and polemical opinion columns in terms of local politics. Only rarely do some lighter pieces emerge in relation to toponymy. Examples that come to mind include a mayor who arbitrarily used his authority to name a street after his mistress; or technical mistakes in the transcription or transliteration of Hebrew, Arabic or Latin names. In this regard, we cannot help but mention that one of the letters in the Hebrew transcription of the suffix -ville in Brazzaville was missing on the Holon signpost until recently. ${ }^{\mathrm{I}}$ Yet, the most intriguing aspect of this very signpost was its geographic (dis)orientation: just beneath the toponym Brazzaville, a short Hebrew explanation stated that the city was "the capital of Congo in East Africa" (Figure I).

Could it be that the Congo, formerly part of French Equatorial Africa - actually located in the central western part of the continent - and its capital Brazzaville were relocated eastwards, toward a distance of some two thousand kilometers? There are general confusions about the Congos of another kind. The same toponym is being used

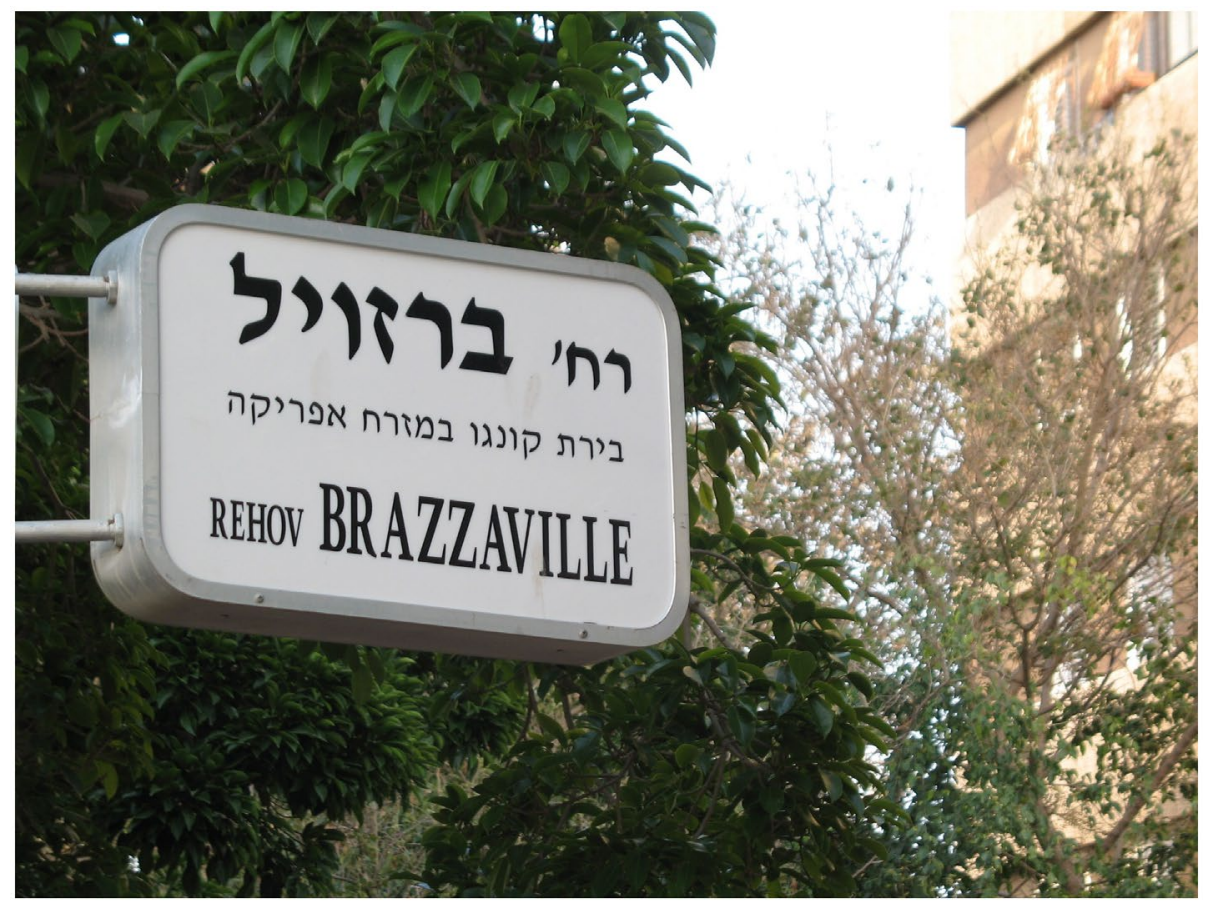

FIGURE 1 The street sign of Brazzaville Street, Holon, Israel. The sub-title reads: “Capital of Congo in East Africa" (photograph LB, April 2014) 
for two countries: the former French Congo (sometimes referred to as Congo-Brazzaville or Congo-Brazza to differentiate it from the "other" Congo); and the former Belgian Congo (renamed Congo at independence, then Zaire, and lately Democratic Republic of Congo, with Kinshasa, ex-Leopoldville (!), as capital). This toponym is also used for the river running between them (with Kinshasa and Brazzaville facing each other on opposite banks), so that people who are unfamiliar with African history and toponymic changes can easily be mistaken. For all that, we have no knowledge of any East African Congo.

Or could it be that nobody, until recently, ever noticed, and that we were among the firsts to read the signpost with amusement? This seems highly probable since Brazzaville Street is short and far from being busy, easy just to pass by at its junction with the main road, Ma'apilim Street. The latter toponym commemorates the "illegal" Jewish refugees who had tried to reach the shores of British Mandate Palestine mainly following World War II, and were treated harshly by the British regime - thus, this toponym conforms to Israel's general toponymic climate. Ma'apilim Street leads to the nearby locally popular site - the "Pillbox", a generic name for each of a series of round concrete guard posts built during the British Mandate - used for picnics and barbecue by the neighborhood's residents. The neighborhood is considered relatively underprivileged in Holon, inhabited by Jews of eastern origin, newcomers of Russian origin, and a growing community of ultra-Orthodox Sephardi Jews. It also contains a few tens of informal structures whose occupiers have refused, since 1948 , to be relocated in rehousing programs. These structures are situated to the foot of the hill of the Pillbox, right in front the Ma'apilimBrazzaville corner (Figure 2).

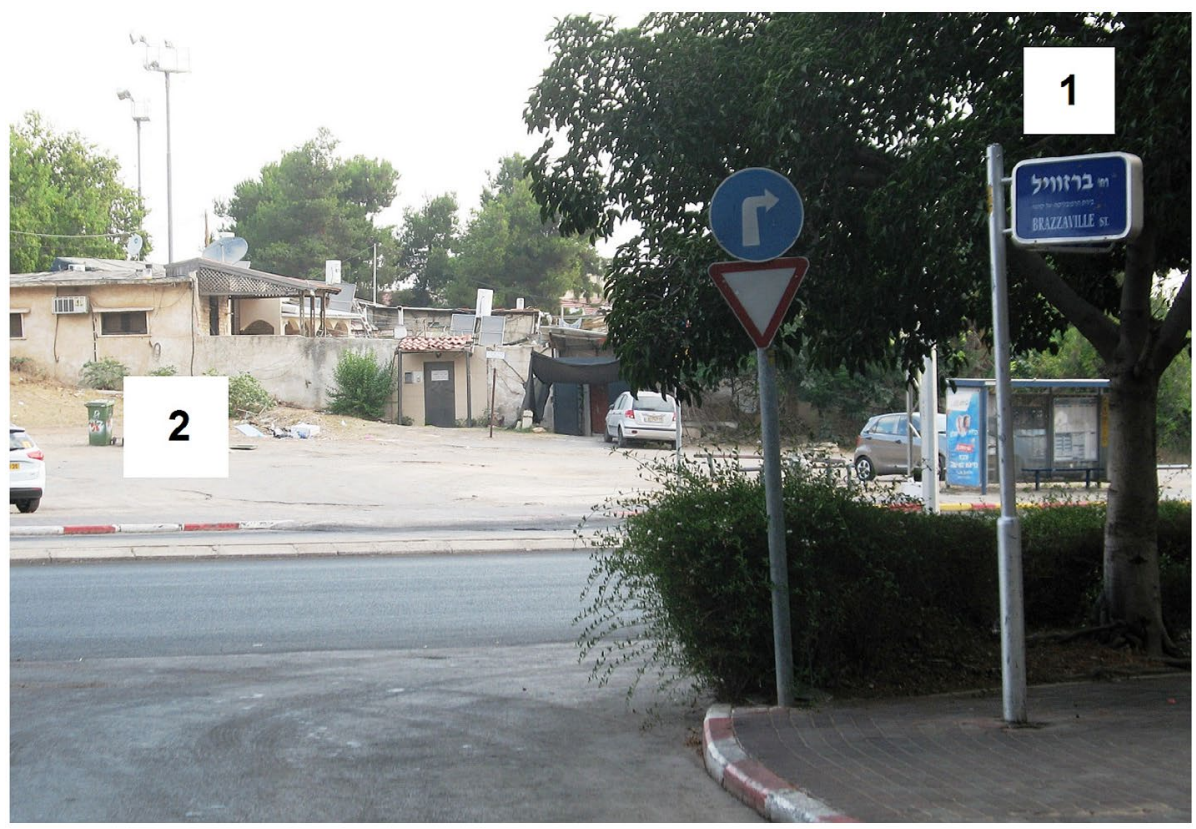

FIGURE 2 Corrected street sign reads: "Brazzaville Street, the Capital of the Republic of the Congo" [1]; together with an informal habitat across the Ma'apilim Street, to the foot of the Pillbox Hill [2] (photograph LB, August 2017) 
The indifference and disregard on the part of local residents to the mapping of Brazzaville during the past few decades of this street sign's life have coincided with the sense of geographic misplacement on the part of the municipal council that could after all perhaps be forgiven: the State of Israel had yet to exist in the Imperial period of the "scramble for Africa", the same period when Palestine itself was subjugated to the Ottoman Empire, later to be trusted to the British Mandate, its pillbox guard posts and rigid immigration policies. It might indeed be an innocent mistake in a country that has never exercised colonial power, at least not officially, and certainly not in Africa (Gregory 2004; Yiftachel 20I0). However, following our report published in 2014 in a local newspaper about the mistakes in this sign, Holon's municipality replied to the newspaper that these would be corrected ${ }^{2}$ - and indeed the signage has been recently changed (see Figure 2), together with a general renovation of the street signs in the entire vicinity (the blue iron plaques with the white script are a typical British-colonialism heritage).

The Quay of Brazza intrigued us for exactly opposite reasons to Holon: the intimate connection of Bordeaux with Africa from the times of the slave trade (Saugera 20I2) and later the colonial era (Lozère 2007); and the sheer absence, here, of any tradition of debate on toponymic matters. A fluvial harbor, Bordeaux developed mainly on the left bank of river Garonne. Our Quay of Brazza is on the other side, a location that offers stunning views of the blond stone façades on the left bank - especially the Chartrons district, the once headquarter of Bordeaux's engagement in the Triangular Trade.

Between the late seventeenth and early nineteenth centuries, ships loaded in Bordeaux deported an estimated I50,000 enslaved Africans to the Americas. This is admittedly far behind Nantes, a city responsible for over 450,000 deportations. Nantes, however, decided in recent years to confront its slavery past and established a Memorial to the Abolition of Slavery that has become an iconic symbol of the city. For its part, the city council of Bordeaux sticks to the argument that Bordeaux built its prosperity less on the slave trade as such (i.e. the sale of slaves) than on straightforward two-way commerce with the Caribbean - which is perfectly true, just as true as the fact that the sugar, cocoa and other colonial commodities carried to Bordeaux were produced through slave labor.

DiversCités, a militant association that has since wound itself up, undertook in the early 2000 s a documentary project leading to the identification of two dozen streets, most of them in the Chartrons, that are still named after people/families who built their wealth from the slave trade or slave labor (Pétrissans-Cavaillès 2004, 82-III). A campaign ensued to have the names changed or, at least, to install memorial plaques. It was met with political silence and a polite indifference shared by local academics, the local press, and the public. The campaign ended in April 20I0, when, in a gallant last stand, Divers Cités activists placed stickers bearing the inscription "négrier" (slaver) on the most contentious street signs. The Office of the Mayor dismissed the operation as "outrageous", and not a single street name was changed.

In contrast to the homogeneous alignment of buildings on the left bank, the right side of the Garonne has a suburban appearance, with its grassy shore, vacant lots, and the Quay of Brazza bordering railway wasteland. The geography of toponyms amazingly overlaps this material contrast, adding to it a symbolic dimension. Brazza, facing the dense network of slavery-related street names across the muddy river, evokes an anti-slavery campaigner who first sailed to Africa on an anti-slavery mission and then, 
as explorer and later governor-general of the French Congo, repeatedly continued to oppose slavery and its colonial avatar — forced labor.

For sure, Brazza was no less a colonizer: his Friendship Treaty with Makoko Iloo (1880), who ruled over the Nkuna area that was to become Brazzaville, was just one of the many examples of African rulers placing themselves under the protection of the French flag in the late nineteenth century, without being in a position to apprehend the implications of what they signed. Yet Brazza turned out to be an unusual kind of governor-general (I886-I898), whose social and wage policies in French Congo (right bank of the river) contrasted heavily with the slavery-like conditions and extreme brutality of the concessionary regime that was implemented in its Belgian counterpart (left side). He was ultimately dismissed due to poor colony profits and journalist reports that branded him a "lax person" and a "negrophile." Concession holding companies were then introduced in French Congo too, and colonial exactions soon resembled those across the river. Brazza returned only once to the Congo, years later, to investigate cases of extreme colonial brutality. He was coldly received. His health deteriorated during the four-month mission and, on the way back to Bordeaux, he was hastily brought ashore in Dakar, Senegal. He died there, in September I905, officially from dysentery, though his widow claimed he had been poisoned. Brazza received state funeral honors in Paris, but the National Assembly voted to suppress his potentially explosive report. The disillusioned widow consequently had his body exhumed and reburied in Algiers, with the epitaph: "A memory untainted by human blood."

The reluctance of Bordeaux's politicians to confront their city's role in the history of slavery and colonial violence not only echoes the more expected lack of concern on part of Holonians, but also mirrors national endeavors to commemorate selectively the colonial past (Blanchard, Nicolas, and Lemaire 2005), such as the exhibition on Brazza originally inaugurated at the Archives nationales d'outre-mer (ANOM) in Aixen-Provence in winter 2007. ${ }^{3}$ A century after his death, Brazza remains a distinguished character, one of the least controversial in French colonial history. Yet few Bordelais seem to know that the Quay of Brazza is named after him. During random interviews conducted in July and August 2017 right under a Quay of Brazza street sign (Figure 3), it appeared that more people connect the Brazza name with the city of Brazzaville (Brazza in its short and popular form) than with Brazza the explorer. ${ }^{4}$

Surprising as this confusion may seem, it might be explained by the evolution of language use, against a backdrop of interiorized toponymic conventions. Contrary to Holon, where an explanation appeared necessary to (wrongly) locate Brazzaville in (East) Africa, the Bordeaux street sign shows no other information than the explorer's name (see Figure 3). The French wording "Quai de Brazza” could certainly be explicit enough in the early twentieth century, when Pierre Savorgnan de Brazza was widely referred to as de Brazza ("de" being a nobiliary particle), but language use has since changed, and the same person is at present best known only as Brazza.5 In French toponymic usage, generic street names (i.e. street, quay, alley, etc.) are directly followed by the specific name when the latter is one of a person ("de Brazza”). When the specific name is that of a city or a country, it is normally preceded with a preposition like "de" or "du" (as in "Quai du Sénégal” or "Allée de Bristol”, both in Bordeaux) — and this widely accepted norm indeed suggests reading "Quai de Brazza” as a quay named after a geographical place called Brazza(ville). 


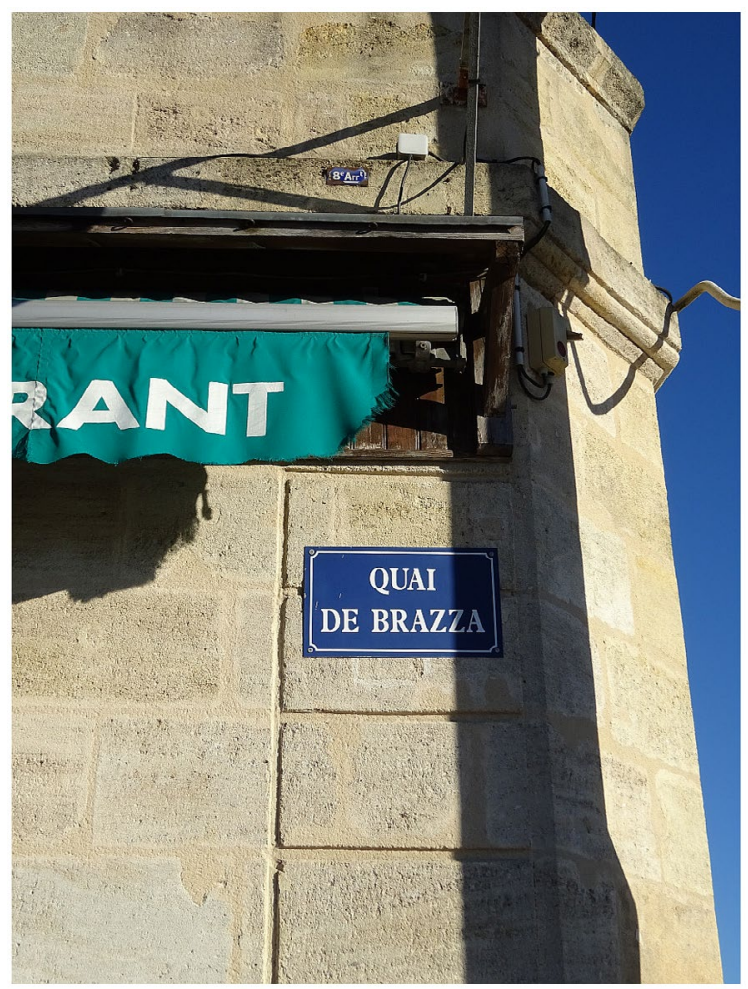

FIGURE 3 A perfectly correct street sign, yet more frequently associated with Brazza, the short name of Brazzaville, than with Brazza the explorer (photograph MB, August 2017)

Still on the Garonne's right bank, in both geographic and symbolic proximity to the Quay of Brazza, a street sign indicates a recently-established Toussaint Louverture Square. The place is actually not a square (not more than Congo is an East African country), it is rather a clearing within a tree-planted promenade, but it commemorates the rebel slave leader who initiated the Haitian Revolution. Toussaint, whose younger son lived and died in Bordeaux, already had a cul-de-sac named after him. He now has a statue in the center of this "square", which was donated to the city of Bordeaux by the Republic of Haiti.

By the way, Toussaint and Brazza were not far from enjoying the company of Nelson Mandela. A brand new bridge (20I3) connecting the Quay of Brazza with the edge of the Chartrons was about to be named after the South African hero and reconciliation champion. For once, the regional daily asked its readers to propose names and that of Mandela came high on the list. Not too surprisingly, however, the city council decided to name the bridge in honor of former mayor Chaban-Delmas. A blameless figure in the French Resistance, Chaban's own brand of “reconciliation” (and durability as mayor) was grounded in enabling collaborationist acts with Nazi Germany by a number of local notables and businesses. In this, he too is relevant to our reading of the namescape, as very representative of a "tradition of political moderation" (as it is locally referred to) 
or, in other words, of the enduring taboos of Bordeaux regarding inconvenient chapters in its history (Bonin 2010, I3-I9).

Visits to the city archives of both Holon and Bordeaux throw some light on the contexts in which Brazzaville Street and the Quay of Brazza were named. In Holon, the name Brazzaville was set in the heydays of Israel-Africa relations in the early I960s, ${ }^{6}$ which were also the age d'or of Franco-Israeli relations. ${ }^{7}$ Holon was visited by the vice-president of Congo-Brazzaville in 1962; and established a twinning alliance with the port city of Tamatave (Toamasina) in Madagascar in the following year. The latter toponym also turned into a street name in the vicinity of Brazzaville Street. Tamatave Street had been designated as well to commemorate the ceremonious visit of the then mayor of Holon, Pinhas Ayalon (in office 1953-・1987), to this overseas city in 1963, and his hosting of a delegation from there in the same year (Figure 4).

However, most African countries aligned themselves with the Arab Bloc and severed official diplomatic relations with Israel shortly before, during, or after the I973 ArabIsraeli War. The government of Congo-Brazzaville was one of the first to do so, in December I972, also due to radical changes in regime and its attitude towards the West

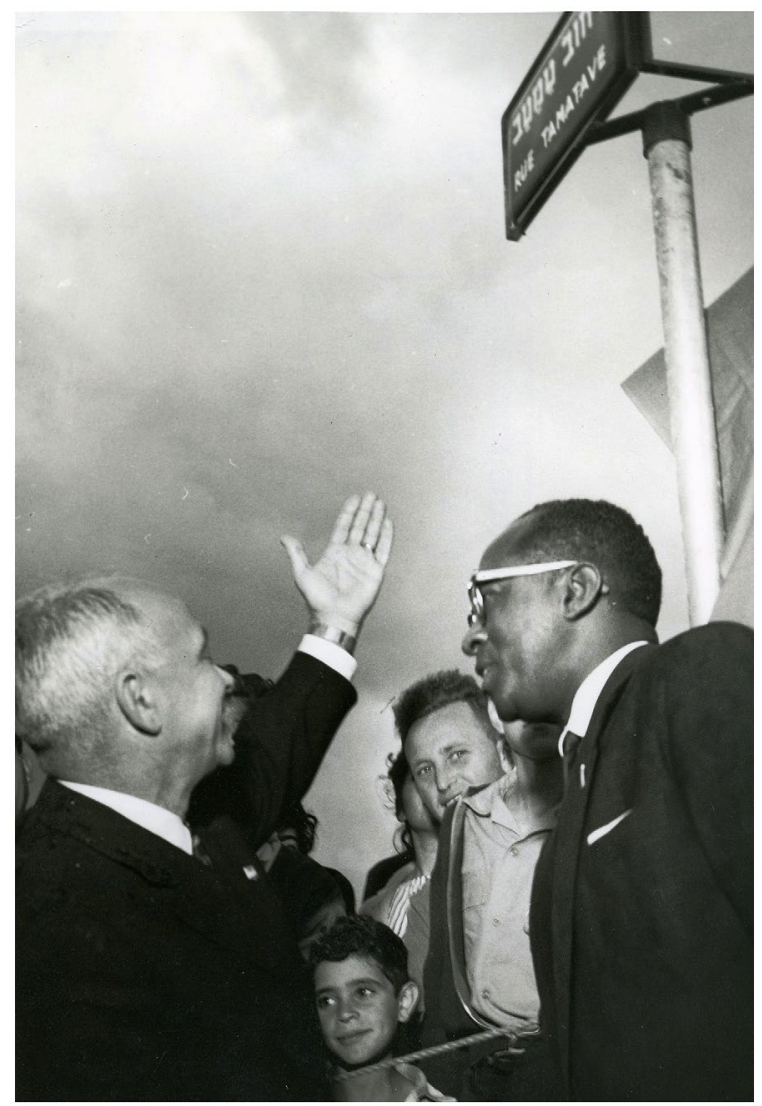

FIGURE 4 The mayors of Holon and Tamatave in the inauguration ceremony of Tamatave Street in Holon in the winter of 1963 beneath the street sign (courtesy of the Museum and Archives of the History of Holon) 
and Israel. This move provoked worries, surprise and criticism on the part of the Israeli media and public, and a feeling of great mistrust (Oded 20II, I25). ${ }^{8}$

In response, Holon's residents of Brazzaville Street requested Ayalon, the "father of Holon", to change their street's name. Ayalon consulted with the Israeli Foreign Office, which examined the matter and decided that the street name should not be changed, opining that it was necessary to differentiate between the hostile attitude of the Congolese government and the friendship that exists between the Congolese and Israeli people. Oddly enough, in spite of the contextual debate that engaged the street's residents, the city's authorities and the governmental office, no one apparently considered to correct the geographical dissonance implied in a street sign that relocated Brazzaville from one part of the vast African continent to the other.

As for Tamatave Street, the municipality of Holon renamed it in 2005 , regardless of the then state of Israel-Madagascar relations (Madagascar had cut ties with Israel in I973 and restored them in I994). The municipality, without consulting the city council, changed the name into Rehavam Ze'evi Street - after a right-wing politician who had promoted a transfer of the Palestinian population. ${ }^{9}$ This move resulted in a protest on the part of a leftist member of the city council, which yield no fruits; but here we enter into the more prevalent Israeli ambiance regarding commemorative street naming, implied earlier in this article.

In Bordeaux, the naming decision took place on 6 February I906, in the aftermath of Brazza's state funeral. The city council named another quay on that very day and, no less odd than the geographic dissonance in Holon, it showed a remarkable sense of geographic harmony. The other quay was named after Hubert Prom, a pioneer in the trade, banking, and political networks of Bordeaux's influence in nineteenth century Senegal (Péhaut 2008). It is located in the dock area of Bacalan, which itself is an extension of the neighboring Chartrons on the left bank - just as the slavery and colonial eras were successive (and at times overlapping) stages in the same imperial history. The city council could have named Hubert Prom the right bank quay, and Brazza the left bank one. They chose the opposite. In so doing, they allowed - most certainly unintended - our geographic imagination to wander across a dual namescape.

From a narrow technical standpoint, street names and street signage are intended to facilitate spatial orientation. Our Brazzaville Street in Holon is in this regard directed first and foremost at Holon's residents, not at the inhabitants of Congo. From the bottom up, we can only ask to what extent the location, or even the existence of Holon, nowadays troubles the urban majority of Brazzaville; and to what extent the working-class residents of Holon care whether Brazzaville is in east, west, north or south Africa. Technically, it makes no difference for the purpose of orienting oneself in Bordeaux whether the Quay of Brazza stems from an explorer or from an African city. In informal use, Brazza has indeed evolved into the popular name of a large area that spreads into the interior of the right bank, well beyond the river shore. The area was further nicknamed Brazzartville (i.e. "art city of Brazza"), , ${ }^{\text {10 }}$ a designation that clearly evokes more the Congolese Brazzaville than Pierre Savorgnan de Brazza. The name Brazzartville emerged on the occasion of the 2014 session of Agora, Bordeaux's Biennial of Architecture, which held several events in and among the many artist squats and decrepit warehouses of the area (Figure 5). 


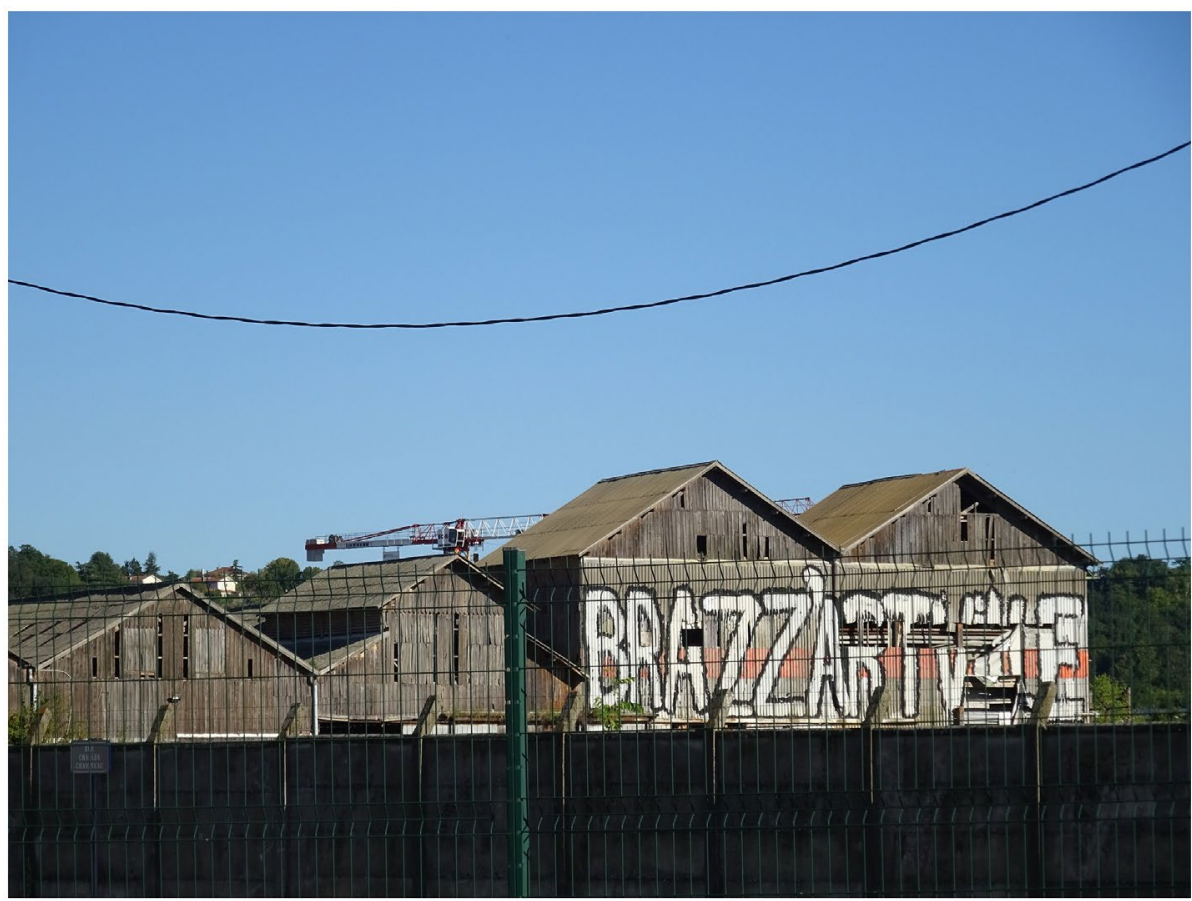

FIGURE 5 Warehouses on the Quay of Brazza, still bearing the inscription "Brazzartville" painted on the occasion of Bordeaux's Biennale of Architecture in 2014 (photograph MB, August 2017)

These re-readings or re-imaginings of the Quay of Brazza, no less than the contrasted fortunes of Brazzaville and (ex-) Tamatave Streets in Holon, invite considering street names and signage as written texts in their own right, requiring the interpretive cooperation of readers to acquire meanings. In this textual perspective, the meaning of a name "stems not for its 'memorial content', but from the content the user attributes to the name, based on his or her own references" (Richard 2009, 5). For all that, street names are generally not "open works" in the strong sense of Umberto Eco, implying a deliberate intention to grasp the "full emotional and imaginative resources of the interpreter" (Eco I989, 9). As a rule, street-namers and signage-writers value univocal meanings rather than poetry and suggestiveness. And yet there always remains room for interpretation, if only because toponymy and signage, beyond being signifiers of spatial orientation, also serve as supports or stimuli for mental mapping, geographical imaginations, and broader narratives. The privilege to stimulate and (dis)orient such cognitive processes is shared between the namers, whose name selection settles the namescape, and those who create the actual signage with or without a few further words of (dis)information. In the final instance, however, it is the street sign's reader who interconnects, assembles and re-assembles the names and other pieces here and there. As we hopefully have shown earlier, through the example of contrasted namescapes on the banks of river Garonne, ultimately the reader re-imagines the city according to his or her own sensibility, background, and motion. As with any written text, he or she always has the last word. 


\section{Conclusion}

In this article, the histories and present-day policies with regard to two Brazza-related toponyms were brought together in a discursive and challenging way. The interconnection between the two different historical and socio-political contexts of Brazzaville Street in Holon, Israel, and Quay of Brazza in Bordeaux, France - enabled a more nuanced and critical view on place naming processes by creating original and novel interpretations. In addition, against the background of Eurocentric tendencies in recent critical toponymic studies, which tend to deal with European/Western geographies and topics, centered on nationalism, revolutions and wars of independence, by tying France, Israel and the Congo together, this article provides a glimpse of nomenclature beyond Europe. We have therefore embraced the approach of "entangled histories" through an examination of the variety of interactions between variegated geographical and socio-political contexts, histories, and time spans in terms of nomenclature in a flexible way. Rather than concentrating on a single site-related toponymic process in an essentialist way, we have examined the two sites of Holon and Bordeaux in the light of "Brazza" inscriptions in an interactive way, intertwining between their different colonial and postcolonial heritages. This entanglement reflects not only urban practices, experiences and memories in situ, but it rather promotes a more inclusive and transnational interpretation of place naming.

\section{Acknowledgements}

The authors would like to acknowledge the generous assistance on the part of the municipal archives' staff in both cities: in Holon, Elisheva Aldman, archivist and Smadar Spector Danon, Museum and Archives Director; and in Bordeaux, Myriam Valatte and Christophe Diaz, archivists.

\section{Notes}

I. If the letter "vav" (१) is not doubled and the script is without punctuation (most of the vowels in Hebrew, as in Arabic, are marked separately and their marking is not mandatory), the toponym can be read as "Brazoyl.".

2. "The municipality of Holon transferred the Congo into East Africa." Ha-Shikma 2I, May 20I4, p. 32; with the municipality's reply on the same page (both in Hebrew).

3. Available online since at http://www.brazza.culture. $\mathrm{fr} / \mathrm{fr} /$ index.html (visited 6 November 20I7).

4. We interviewed 40 passers-by. To the question: "Who or what does the street sign refer to?", only six mentioned Brazza the explorer, 22 mentioned "a city in Africa", and I2 said they did not know.

5. The earlier-mentioned ANOM exhibition illustrates this shift. While the majority of archival documents on display dating from Brazza's lifetime refer to him as de Brazza, the accompanying texts written for the exhibition simply state Brazza.

6. Development cooperation with the new and decolonizing countries of Africa was a top priority in Israel's foreign policy under Golda Meir's tenure as
Foreign minister, I956-I966. The then presence of Israel in all sub-Saharan independent countries (with the sole exceptions of Somalia and Sudan) was no less grounded in strong ideological-humanistic considerations and a somewhat romantic fellow feeling. Israeli assistance in agriculture, security, and infrastructure development, was welcomed by the first generation of sub-Saharan leaders out of their affinities for a small country that successfully performed in many areas, partially similar to theirs; and their initial reluctance to rely too much on the former-colonizing nations (Oded 20II, 3-28).

7. Suresnes, near Paris, was the first city that signed a twinning agreement with Holon. The "ideal" phase of Franco-Israeli relations occurred between Egypt's nationalization of the Suez Canal in 1956 and Algeria's independence in I962, following which French foreign policy prioritized the development of economic relations with Arab countries. FrancoIsraeli relations deteriorated at an accelerated pace at the time of the Arab-Israeli Wars of 1967 and I973, in spite of the clear pro-Israeli attitude of the French public at that time (Rosman 20I4, 88-I25, I90-I9I). 
Example to this is an emphatic letter "For Israel and the city of Holon", sent to Holon by its twin Suresnes directly after the 1973 War.

8. Partly as a result, the renewed Israeli presence in subSaharan Africa since the I990s is based much less on ideological rationale, as occurred in the I960s, and more on public-private and other economic or diplomatic partnerships.

9. Moreover, the renaming event took place on the Memorial Day for Yitzhak Rabin, a leftist Prime
Minister who, in promoting the peace process with the Palestinians, was assassinated by a rightist terrorist in winter I995 (Ze'evi was assassinated in 200 I by Palestinian terrorists).

10. The letter "t" is not pronounced (as it would be in the English word "art"). Thus, the name is sounded "Brazarvil", which also conveys a play of sounds with the French word bazar - less in the sense of (Arabic) "bazaar" than of (English) "shambles" or (Hebrew) "balagan"

\section{Disclosure statement}

No potential conflict of interest was reported by the authors.

\section{Bibliography}

Azaryahu, M., and A. Kellerman. 1999. "Symbolic Places of National History and Revival: A Study in Zionist Mythical Geography." Transactions of the Institute of British Geographers 24 (I): I09-I23.

Bar-Gal, Y. 1989. "Naming City Streets: A Chapter in the History of Tel Aviv, 1909-1947." Contemporary Jewry IO (2): 39-50.

Bar-Gal, Y. I999. "On the Tribal-Elders, the Successors and the New Ones in the Israeli Geography." Horizons in Geography $5 \mathrm{I}(\mathrm{I}):$ 7-39. in Hebrew.

Ben Arrous, M. 20I2. “Géographies de l'ailleurs. Imaginaires et production de l'espace.” Unpublished PhD thesis in geography, Université de Rouen.

Ben Arrous, M., ed. 2015. African Studies in Geography from below. 2nd ed. Dakar: CODESRIA.

Ben-Rafael, E., E. Shohamy, M. Amara, and N. Trumper-Hecht. 2006. "Linguistic Landscape as Symbolic Construction of the Public Space: The Case of Israel." International Journal of Multilingualism 3 (I): 7-30.

Benvenisti, M. 2000. Sacred Landscape: The Buried History of the Holy Land since I948. Berkeley, CA: University of California Press.

Bigon, L., ed. 2016. Place Names in Africa: Colonial Urban Legacies, Entangled Histories. Cham: Springer.

Bigon, L., and A. Dahamshy. 20I4. "An Anatomy of Symbolic Power: The Israeli Road-Signs Policy and the Palestinian Minority." Environment and Planning D: Society and Space 32 (4): 606-62I.

Bigon, L., and Y. Katz. 2017. "De-Colonising Place-Name Historiographies: (Urban) Africa via Europe and Israel/ Palestine." Presented at the Specialist Session "The Pragmatics of Place: Colonial and Postcolonial Perspectives. International Pragmatics Association (IPrA) Conference, Belfast, July.

Blanchard, P., B. Nicolas, and S. Lemaire, eds. 2005. La fracture coloniale. La société française au prisme de l'héritage colonial. Paris: La Découverte.

Bonin, H. 20Io. Les tabous de Bordeaux. Bordeaux: Le Festin.

Eco, U. 1989. The Open Work. Translated by A. Cancogni. Cambridge, MA: Harvard University Press.

Fishman, J., M. Gertner, E. Lowy, and W. Milán, eds. 1985 . The Rise and Fall of the Ethnic Revival: Perspective on Language and Ethnicity. Berlin: Mouton de Gruyter.

Foote, K., and M. Azaryahu. 2007. "Toward a Geography of Memory: Geographical Dimensions of Public Memory and Commemoration." Journal of Political and Military Sociology 35 (I): I25-I44.

Gregory, D. 2004. The Colonial Present: Afganistan, Palestine, Iraq. Oxford: Blackwell.

Jones, R., and P. Merriman. 2009. "Hot, Banal and Everyday Nationalism: Bilingual Road Signs in Wales.” Political Geography 28 (3): I64-I73.

Katz, Y I995. "Identity, Nationalism and Place Names: Zionist Efforts to Preserve the Original Local Hebrew Names in Official Publications of the Mandate Government of Palestine." Names 43 (2): I03-II8.

Katz, Y. I999. "Reclaiming the Land: Factors in Naming the Jewish Settlement in Palestine during the Era of the British Mandate." In These Are the Names: Studies in Jewish Onomastics, edited by A. Demsky, vol. II, $63-\mathrm{II} 2$. Ramat Gan: Bar-Ilan University Press

Light, D., I. Nicolae, and B. Suditu. 2002. "Toponymy and the Communist City: Street Names in Bucharest, I948I965." GeoJournal 56 (2): I35-I44.

Lozère, C. 2007. Bordeaux Colonial, I850-I940. Bordeaux: Editions Sud-Ouest. 
Milo, D. 1997. "Street Names." In Realms of Memory, edited by P. Nora, 363-389. New York, NY: Columbia University Press.

Nash, C. I999. "Irish Placenames: Post-Colonial Locations." Transactions of the Institute of British Geographers $24(4): 457-480$.

Oded, A. 20I I. Africa and Israel: A Unique Case of Radical Changes in Israel's Foreign Relations. Jerusalem: Magnes Press. in Hebrew.

Péhaut, Y. 2008. “Le réseau d'influence bordelais: la ‘doyenne' Maurel \& Prom jusqu'en I9I4." In L'esprit économique impérial (I830-1970), edited by H. Bonin, C. Hodeir, and J. F. Klein. Groupes de pression \& réseaux du patronat colonial en France \& dans l'empire, 225-242. Paris: Publications de la SFHOM.

Pétrissans-Cavaillès, D. 2004. Sur les traces de la traite des Noirs à Bordeaux. Paris: L'Harmattan.

Raento, P., and C. Watson. 2000. Gernika, Guernica, Guernica? Contested Meanings of a Basque Place. Political Geography I9 (6): 707-736.

Randeria, S. 2009. "Entangled Histories of Uneven Modernities: Civil Society, Castle Solidarity and Legal Pluralism in Post-Colonial India." In Comparative and Transnational Histories, edited by H. Heinz-Gerhard and J. Kocka, 77-105. Oxford, NY: Berghahn Books.

Richard, M. 2009. Spirit of Place and the Act of Naming: Restoring the Fascination of Geography. UN Group of Experts on Geographical Names. Working Paper 6o(b).

Rose-Redwood, R. 2008. "From Number to Name: Symbolic Capital, Places of Memory, and the Politics of Street Renaming in New York City.” Social \& Cultural Geography 9 (4): 432-452.

Rose-Redwood, R., D. Alderman, and M. Azaryahu. 2010. "Geographies of Toponymic Inscription: New Directions in Critical Place-Name Studies.” Progress in Human Geography 34 (4): 453-470.

Rosman, M. 20I4. La France et Israël I947-I970. De la création de l'Etat d'Israël au départ des Vedettes de Cherbourg. Translated by H. Karas. Tel Aviv: Resling, in Hebrew.

Saugera, E. 20I2. Bordeaux Port Négrier. Chronologie, économie, Idéologie, XVIIe-XIXe Siècles. 2nd ed. Paris: Karthala.

Shohamy, E., and S. Donitsa-Schmidt. 1988. Jews Vs. Arabs: Language Attitudes and Stereotypes. Tel Aviv: Tami Steinmetz Center for Peace Research.

Shoval, N. 2013. "Street-Naming, Tourism Development and Cultural Conflict: The Case of the Old City of Acre/ Akko/Akka." Transactions of the Institute of British Geographers 38 (4): 612-626.

Subrahmanyam, S. 1997. “Connected Histories: Notes towards a Reconfiguration of Early Modern Eurasia." Modern Asian Studies 3I (3): 735-762.

Suleiman, Y. 2004. A War of Words: Language and Conflict in the Middle East. Cambridge: Cambridge University Press.

Werner, M., and B. Zimmermann. 2006. "Beyond Comparison: Histoire Croisée and the Challenge of Reflexivity." History and Theory $45(\mathrm{I}): 30-50$.

Yiftachel, O. 20I0. "From Sharon to Sharon: Spatial Planning and Separation Regime in Israel/Palestine." HAGAR Studies in Culture, Polity and Identities Io (I): 73-106.

\section{Archival sources}

\section{Museum and Archives of the History of Holon}

Items number: 767, I00I-5, 3131, 7508, 9565, I0,043.

Municipal Committee protocols: ${ }^{\circ}{ }_{50-51}$ I 5 August I962; n ${ }^{45}$, I8 November 1973.

\section{Archives Bordeaux Métropole}

Items number: $\mathrm{BIBM}_{4} / 8, \mathrm{I}_{3} \mathrm{D}_{20} \mathrm{O}_{3} \mathrm{I}_{3} \mathrm{D}_{204}, \mathrm{XL}-\mathrm{A} / 227, \mathrm{XL}-\mathrm{A} / 243$.

Municipal Committee protocols: 24 January I906; 2 February I906.

\section{Notes on Contributors}

Liora Bigon is a Senior Staff Member at Holon Institute of Technology and a Research Fellow at the Truman Institute of the Hebrew University of Jerusalem. Interested in colonial urban history, architecture and planning cultures in sub-Saharan Africa, she has published numerous articles, encyclopedic entries, and (edited) books on these topics. 
Michel Ben Arrous is an architect and geographer, currently a researcher at the History Department of Bar-Ilan University. He has published extensively on the epistemology of territory, media and conflict, and the history of geographic ideas and fantasies. A former journalist in sub-Saharan Africa, he also coordinated research with CODESRIA in Dakar, Senegal.

Correspondence to: Dr Liora Bigon, General Studies Department, Holon Institute of Technology (HIT); 52, Golomb St., Holon, 58I020I, Israel. Email: liorab@hit.ac.il 